\title{
Inclusions in anhydrite crystals from blue halite veins in the Kłodawa Salt Dome (Zechstein, Poland)
}

\author{
Tomasz TOBOŁA ${ }^{1, *}$
}

1 AGH University of Science and Technology, Faculty of Geology, Geophysics and Environmental Protection, al. A. Mickiewicza 30, 30-059 Kraków, Poland

Toboła, T., 2016. Inclusions in anhydrite crystals from blue halite veins in the Kłodawa Salt Dome (Zechstein, Poland). Geological Quarterly, 60 (3): 572-585, doi: 10.7306/gq.1274

\begin{abstract}
The occurrence of both the blue and violet halites is one of the most interesting phenomena in nature. Despite numerous laboratory and field works, their origin in natural evaporitic environments has not been satisfactorily explained. In the Kłodawa Salt Dome (Zechstein, Central Poland), blue or violet halites occur relatively frequently. Their accumulations differ in size and intensity of colours. In this paper, petrological features of anhydrite crystals derived from one of the largest outcrops of the blue halite at the Kłodawa Salt Mine are presented. Anhydrite is one of solid inclusions encountered in blue-coloured halite crystals. Special attention was paid to fluid inclusions present in this anhydrite. The microthermometric measurements showed two directions of homogenisation, i.e., towards the liquid phase $(L G \rightarrow L, L L \rightarrow L)$ or towards the gas phase ( $L G \rightarrow G)$. In the former case, the temperatures ranged from 174 to $513^{\circ} \mathrm{C}$, whereas in the latter one, the values from 224 to $385^{\circ} \mathrm{C}$ were measured. The composition of inclusions is relatively variable. We can observe transparent and opaque daughter minerals as well as $\mathrm{CO}_{2}$ in the liquid phase accompanied by a variable amount of methane or hydrogen sulphide. These features of inclusions indicate that anhydrite crystals and, thus, blue halite were formed under the influence of hydrothermal conditions. Observations in the mine workings combined with petrological studies enable to conclude that blue colouration of halite crystals is controlled by three factors: a high temperature, reducing conditions and defects in halite lattice related to tectonic stress.
\end{abstract}

Key words: blue halite, hydrothermal environment, salt domes, anhydrite, epigenetic salt.

\section{INTRODUCTION}

The blue or violet halite crystals are very rare in nature although they were noticed in many salt formations of various ages. They were found, inter alia, in Cambrian $\mathrm{KCl}$-deposits from the southern part of the Siberian platform (Pustyl'nikov, 1975), Mississippian rocks of eastern Canada (Roulston and Waugh, 1983; Waugh and Urquhart, 1983; Davison, 2009), Lower Permian of the Solikamsk Depression in the Ural Foredeep (Vinokurov, 1958; Ivanov and Voronova, 1972; Smetannikov, 2011), within the Verkhnepechora Basin (Ivanov and Voronova, 1968) as well as in the Kramatorsk Series of Donbass (Bobrov et al., 1968), Upper Permian of the Delaware Basin, southeastern New Mexico, USA (Bickham, 2012), Upper Permian (Zechstein) salt deposits of Germany (Borchert, 1959), Cretaceous to Paleogene (Maha Sarakham Formation) of the Khorat Plateau, northeastern Thailand (Suwanich, 1983; Tabakh et al., 1999), Paleogene and Neogene of Northern and Central Iran (Rahimpour-Bonab and Alijani, 2003; Baikpour et al., 2010), and Miocene of the Carpathian Foredeep in Ukraine

\section{*E-mail: tob@geolog.geol.agh.edu.pl}

Received: October 13, 2015; accepted: December 11, 2015; first published online: February 2, 2016
(Koriń, 1994). The nature of such colouration has been investigated for over 150 years by many researchers representing various fields. One of the first scientists who undertook in-depth analysis of blue halite was Kreutz (1892). He analysed the results of experiments and observations made by previous authors, and completed a series of his own experiments on natural and synthetic halite crystals. Based on these data Kreutz (1892) concluded that: (1) blue colour does not fade when halite crystals are heated in oxygen-free atmosphere, but disappears under "flame of oxidation"; (2) previously discoloured and naturally colourless halite crystals become coloured when heated in potassium or sodium vapours, although not all originally colourless crystals become coloured; and (3) under the same experimental conditions, synthetic halite crystals are not coloured.

These and other observations and experiments enabled Kreutz (1892) to present the theory that the colour of halite crystals originated from very small admixtures of iron or other metals, which were below the detection limits of analytical methods used at that time.

The development of modern analytical methods since the late 19th century has provided new valuable data. The new studies (see Sonnenfeld, 1995) focused mostly on laboratory analyses of blue halite properties and on the methods of its colouration, and they gave rise to new hypotheses on the origin of colour in natural halite. It was found that, in addition to the above-mentioned factors, colouration of halite can be obtained by crystallisation from $\mathrm{NaCl}$ - and $\mathrm{KCl}$-saturated solutions con- 
taining $320 \mathrm{~g} / \mathrm{l} \mathrm{MgCl}$, by electric spark puncture and by the action of ionizing $U V, \alpha, \beta$ and $\gamma$ radiations. Moreover, it was also observed that the physico-chemical properties of artificially coloured halite crystals differ from the natural ones. A large number of papers concerning halite crystals colouration were reviewed and discussed by Sonnenfeld (1995). He concluded that most of experimental results were obtained under conditions which do not occur in the nature. He has also questioned the widely accepted view that the colour of natural halite results from radiation caused by radioactive decay of ${ }^{40} \mathrm{~K}$ isotope.

In recent years, detailed observations and studies on the occurrence of blue halite were carried on at the Kłodawa Salt Dome (Natkaniec-Nowak and Toboła, 2003; Toboła et al., 2007; Janiów et al., 2008). As a result of this research, 19 key exposures were described together with their relations to the surrounding rocks and mineral composition, as well as with visual estimation of the intensity, variability, hue and saturation of colour. Standard microscopic examinations of thin sections of blue halite revealed the presence of birefringent areas in the crystals. Unfortunately, their correlation with coloured areas was difficult because halite colours are invisible in thin sections (Heflik et al., 2008). Similarly, in thick sections, in which blue colour is clearly visible under transmitted light, characteristic birefringence does not coincide with coloured areas, but both features coexist side by side. Moreover, observations of thick sections revealed also the common presence of intergrowths, both transparent and opaque. The SEM-EDS examinations showed that transparent intergrowths are the mixtures of sodium, magnesium and potassium chlorine compounds, whereas opaque intergrowths are iron sulphides, although their crystal habits do not correspond to well-known and most common minerals such as pyrite or marcasite (Toboła and Natkaniec-Nowak 2008). The fluid inclusion studies demonstrated the presence of several inclusion types differing in geometric patterns. The inclusions are filled with highly concentrated brines as well as with gases $\left(\mathrm{CO}_{2}, \mathrm{CO}, \mathrm{COS}, \mathrm{O}_{2}, \mathrm{~N}_{2}, \mathrm{CH}_{4}, \mathrm{C}_{3} \mathrm{H}_{8}\right)$, with aromatic hydrocarbons and with liquid, long-chained hydrocarbons (Toboła and Wesełucha-Birczyńska, 2008; Wesełucha-Birczyńska et al., 2008). Structural studies of halite samples with varying degrees of staining showed deformation of the symmetry of regular structure (Zelek et al., 2007, 2014; Stadnicka and Zelek, 2008). All these data clearly demonstrated the complexity of processes leading to the formation of coloured varieties of halite in the salt dome.

The aim of present studies is to estimate the formation temperature of the blue salts. Previous investigations carried out for blue halite crystals suggested in some cases high temperatures, up to $347^{\circ} \mathrm{C}$ (Toboła and Wesełucha-Birczyńska, 2008). However, these data should be treated with caution because of some halite properties such as easy recrystallisation and reaction with solutions contained in inclusions (e.g., Roedder, 1984b). Hence more precise and credible data can be obtained for minerals coexisting with the blue halite. Anhydrite, accompanied by iron sulphides (pyrite) and quartz, is the most common mineral. Such paragenesis as well as the fluid inclusions assemblage (FIA) in anhydrite crystals document atypical conditions of the blue halite formation and the thermal impact on salt rocks.

\section{GEOLOGICAL SETTING}

The Kłodawa Salt Dome is located in the Kujawy region (Central Poland, Fig. 1). This region is characterized by the most complete lithostratigraphic succession and the maximum thickness of the Zechstein salt-bearing formation. Detailed data concerning the relationships of salt-bearing formation to the surrounding rocks, its tectonics, lithostratigraphy and facies changes can be found in a number of publications (see e.g., Dadlez, 2003; Dadlez et al., 1995; Krzywiec, 2004, 2006). The Kłodawa Salt Dome belongs to the Izbica Kujawska-Łęczyca salt ridge, which is considered as the largest salt diapir in Poland. Studies on the diapir structure indicated its strong NW-SE elongation. The length of the diapir is about $26 \mathrm{~km}$, and its width varies from 0.5 to $2 \mathrm{~km}$ (e.g., Werner et al., 1960; Tarka, 1992; Burliga, 2014; Burliga et al., 1995). The geological cross-sections show the asymmetrical shape of the diapir: its NE slope dips moderately eastward at $55-70^{\circ}$, but its SW slope is almost vertical. The diapir is enclosed within deformed Mesozoic (Triassic-Jurassic) and, partly, Neogene deposits, and is covered by Quaternary and Neogene sediments. The Kłodawa salt deposit is built mainly of rocks representing fully developed Zechstein PZ2-PZ4 cyclothems. These are claystones, dolomites, anhydrites, rock salts and K-Mg salts. The lowermost Zechstein cyclothem PZ1 is known only as tectonically transported blocks (Charysz, 1973; Burliga et al., 1995).

The internal structure of the Kłodawa Salt Dome is complicated due to deformation of salt series. The main effect of salt movement during the diapir rising is the piercing of the Older Halite (Na2) by the Younger (Na3) and the Youngest (Na4) halites, as well as the occurrence of tectonic pinch-outs and high-amplitude narrow folds. Such complicated deformation resulted from different rheological properties of rocks. In general, two NW-SE elongated anticlines predominate in the SW and NE parts of the diapir (Fig. 2). These are separated by a deep central syncline built of the youngest salt layers (Charysz, 1973; Tarka, 1992; Burliga, 1994).

An important role in the internal structure of the salt dome is played by epigenetic salts. Their presence is closely associated with salt deformation processes that facilitated migration of solutions. In the Kłodawa Salt Dome the epigenetic salts form veins and accumulations of variable size. Their mineral composition includes large halite crystals as well as polyhalite, carnallite and sylvite (Stańczyk, 1970; Stańczak-Stasik, 1976).

\section{OCCURRENCE OF THE BLUE HALITE IN THE KŁODAWA SALT DOME}

The blue halite is relatively common at the Kłodawa Mine. It was found at all main mining levels and in many interlevel workings, in various rocks of the $\mathrm{PZ2}, \mathrm{PZ} 3$ and $\mathrm{PZ4}$ cyclothems (Natkaniec-Nowak and Toboła, 2003; Toboła et al., 2007; Janiów et al., 2008). The blue halite forms very diverse concentrations with respect to its size and colour, its contact with the surrounding rocks, and the occurrence of accompanying minerals. The halite usually forms very small accumulations (from a few to several centimetres across) hosted in small veins or irregular accumulations of recrystallised salt. Salt crystals sometimes contain intergrowths of sylvite, carnallite and polyhalite (Fig. 3A). The blue colour appears as point clusters or small streaks within single halite crystals. Such accumulations are most common within the Older Halite (Na2) or Younger Halite (Na3).

The larger accumulations of blue-coloured halite crystals reach from a few to, occasionally, several tens of metres in length. Their outcrops were encountered at mining levels 525 , 562,600 and 750 . At the level 525, a continuous zone of blue halite was recognized within the Older Halite (Na2), over $50 \mathrm{~m}$ long and from 4 to $15 \mathrm{~m}$ wide. It extends from the KS29-KS21 chambers through the area of KSc18 and KSc12 cylindrical chambers, and continues towards the KS16a chamber as well as galleries leading to the above-mentioned workings. A characteristic feature of this zone is the occurrence of both 


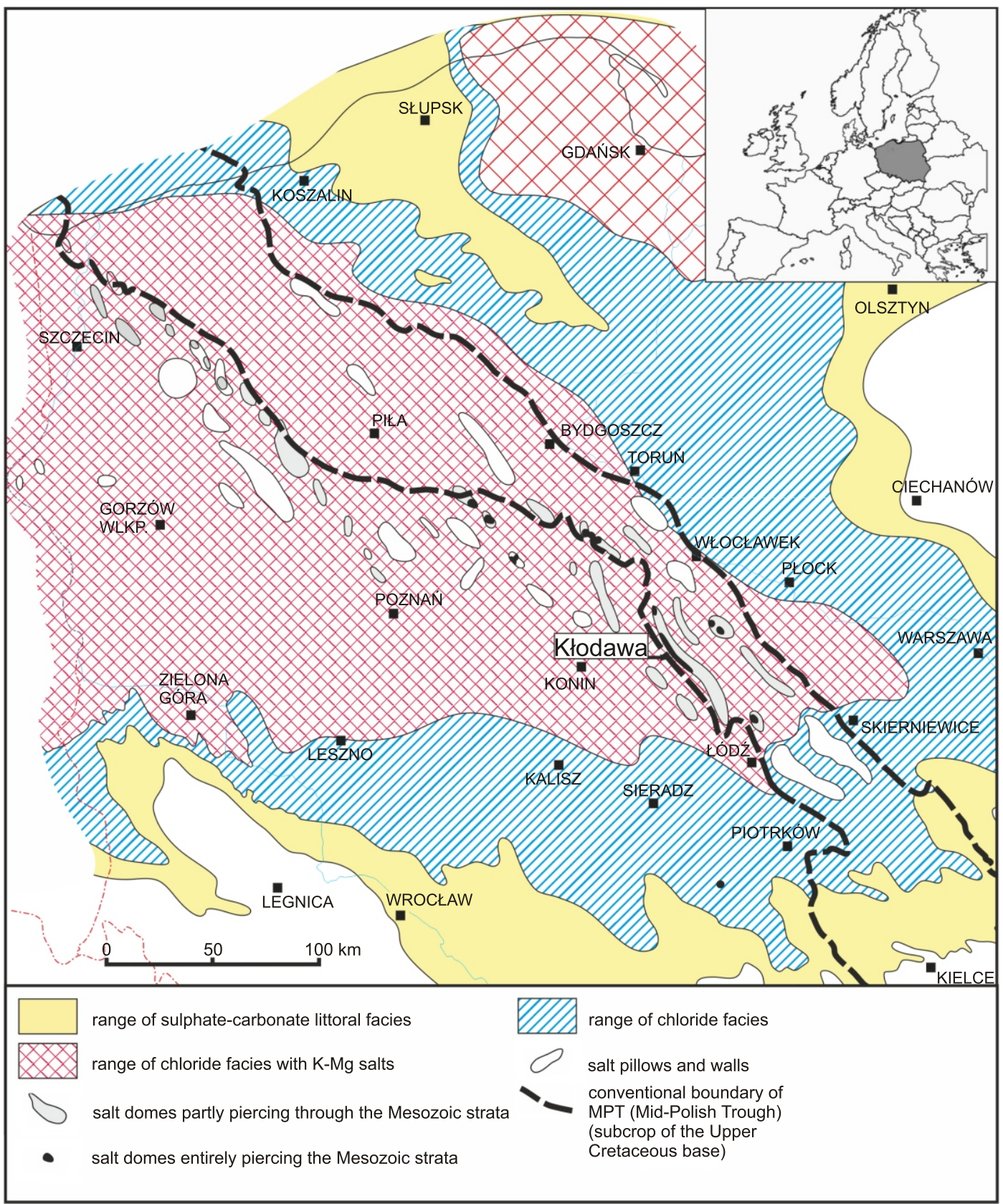

Fig. 1. Part of the Zechstein lithofacies map, and location of salt structures in Poland (after Garlicki and Szybist, 1986)

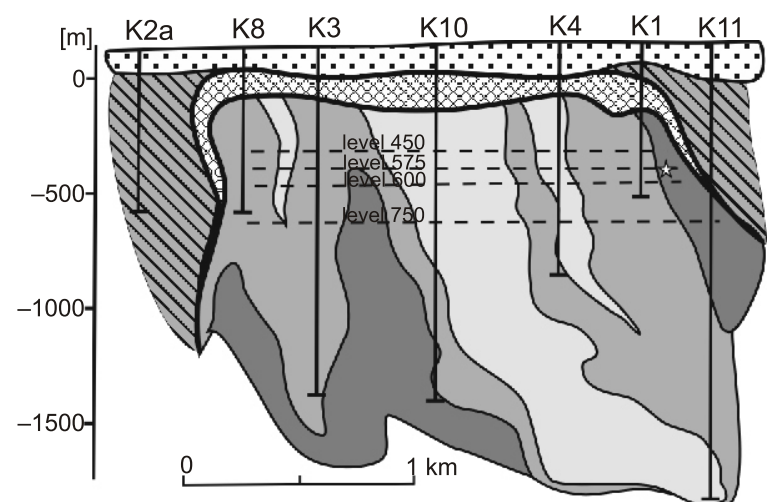

$\because \cdot$ Q+Tr sediments $\square$ Mesozoic sediments $\$$ cap-rock of salt dome $\square$ PZ2 cycle $\square$ PZ3 cycle $\square$ PZ4 cycle K1 - borehole ts sampling
Fig. 2. Geological cross-section through the upper part of the Kłodawa Salt Dome (after Burliga et al., 1995, simplified) 

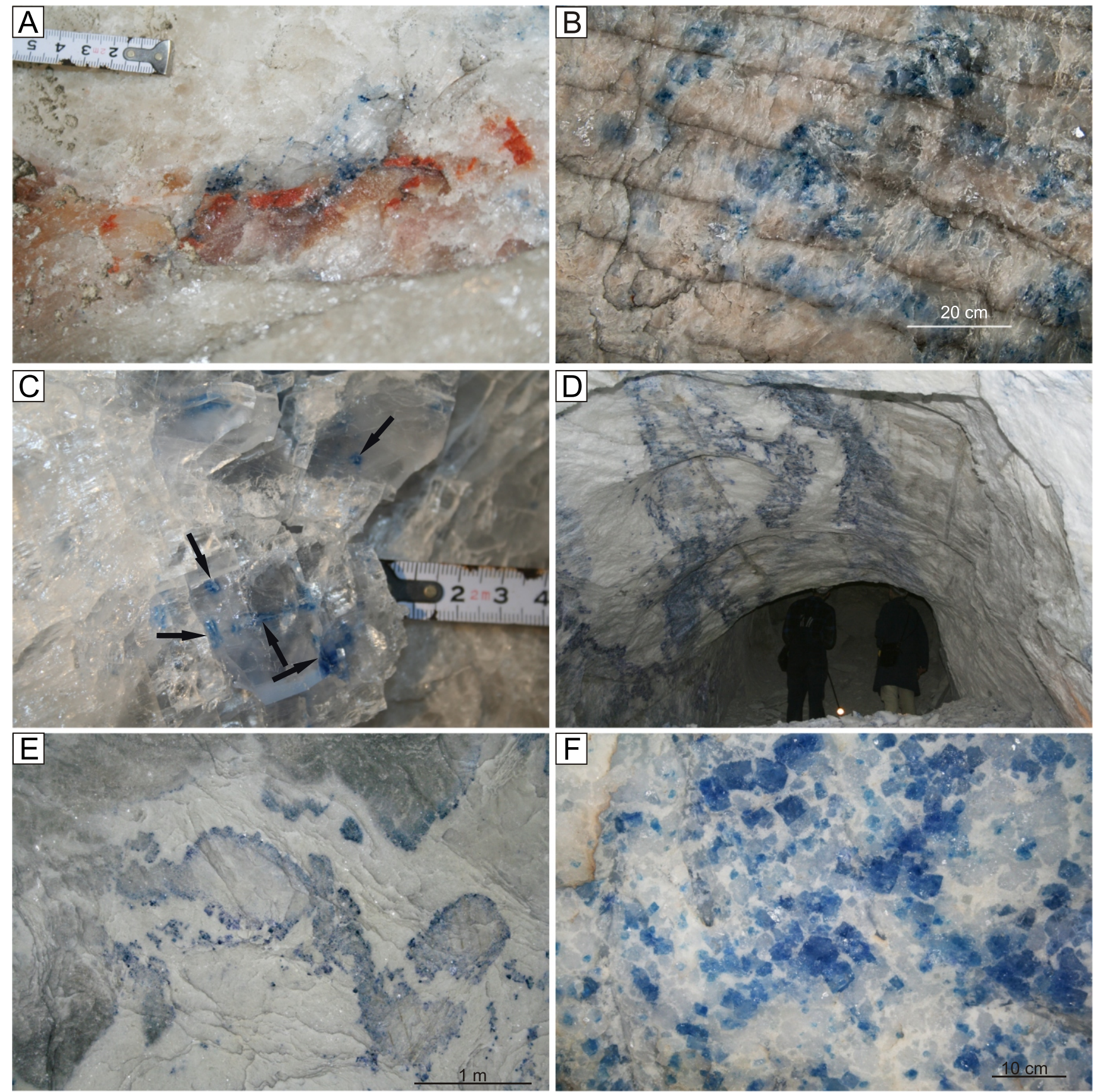

Fig. 3A - small clusters and streaks of blue colour within halite crystal accompanied by carnallite and polyhalite (mining level $600 \mathrm{~m}$, chamber KS1d); B - larger, irregular concentration of blue halite within striped salt (Older Halite) (mining level $525 \mathrm{~m}$, chamber KSc14); C - coarse-crystalline halite with small intergrowths of sylvite (marked by arrows) with blue rim (mining level $630 \mathrm{~m}$, gallery between chambers KS16b and KS17b); D - streaks and elongated concentration of blue halite in white halite and sylvite (mining level $562 \mathrm{~m}$, ventilation gallery between chambers KS38 and KS39); E - blocks of primary striped salt (Older Halite) with blue rims embedded within white epigenetic vein of halite and sylvite (mining level $600 \mathrm{~m}$, roof of chamber KS39); $\mathrm{F}$ - large blue-coloured halite crystals inside a vein of white carnallite with admixture of sylvite (mining level $750 \mathrm{~m}$, crossing of galleries GPT2 and GPT2a) 
epigenetic structureless veins and nests of large halite crystals, and rock salt aggregates with preserved residual "striped" structure (Toboła et al., 2007; Janiów et al., 2008). In the halite crystals, blue colouration shows various patterns. The most common features of the "striped" halites are irregular, spotty accumulations with fuzzy contours and varying degrees of blue colour saturation (Fig. 3B). In the structureless salt aggregates, where halite crystals occasionally exceed $20 \mathrm{~cm}$ in diameter, blue colour is much rarer. It can be observed only in some halite crystals as single spots or spot clusters, up to several millimetres across. Blue colouration is often associated also with transparent solid inclusions varying in size from 0.5 to $2-3 \mathrm{~mm}$, embedded within halite crystals which show thin blue rims (Fig. 3C).

One of the largest accumulations of the colourful halite, extending over a distance of 12 metres (Fig. 3D), is located at the mining level 562 , in the ventilation gallery between chambers KS38 and KS39, within the Older Halite (Na2). The main mass comprises transparent or white halite and sylvite in various proportions. The coloured halite forms strongly elongated streaks of diffused boundaries, up to several centimetres thick, extending continuously through the enclosing white salts. The colour of these streaks changes from light blue through bluish-violet to dark navy blue. Locally, even purple or yellow halite crystals can be found (Toboła et al., 2007; Janiów et al., 2008).

At the mining level 600 in the end part of chamber KS39, there is an extension of the above-mentioned outcrop of blue halite. However, in contrast to the accumulation at the level 562 , the greatest amounts of blue salt occur at the contact of striped primary salts (Na2) and epigenetic sylvinite. Streaks or individual small light-blue halite crystals are observed much more rarely. The most intense blue colour appears along the edges of tectonic blocks of striped halite ( $\mathrm{Na} 2)$ embedded within sylvinite veins (Fig. 3E).

Other major exposures at this mining level were found in the galleries NW I and NE VII (Toboła et al., 2007; Janiów et al., 2008). They are hosted inside laminated salt of the Younger Halite (Na3). Similarly to the above-mentioned occurrences in the ventilation gallery and chamber KS39, the matrix of the vein consists of white epigenetic sylvinite, within which the blue halite forms blurry streaks, up to about $20-30 \mathrm{~cm}$ thick and generally parallel to the course of that epigenetic vein. The largest concentrations of halite showing the highest intensity of blue colour are located at the contact of the vein and the Younger Halite (Na3).

Another variety of large halite accumulation is located at the mining level 750 (Toboła et al., 2007; Janiów et al., 2008) within the Younger Potash Salts (K3). The wall-rocks of the vein are composed of epigenetic carnallite with an admixture of sylvite, in which single crystals of light-blue halite are embedded (Fig. 3F). The coloured halite is generally scattered in the vein as single crystals or small aggregates. Larger accumulations in the form of streaks of darker-blue halite are observed at the contact of the vein with $\mathrm{K}-\mathrm{Mg}$ salts (K3), especially where these salts are accompanied by the rock salt.

\section{MATERIALS AND ANALYTICAL METHOD}

For microthermometric studies we selected anhydrite crystals forming solid inclusions in the blue halite. Halite samples were collected from one of the largest documented exposure of blue salts located in the ventilation gallery at the mining level 562. In these samples, anhydrite crystals are commonly associated with streaks or nests of opaque minerals (Heflik et al.,
2008) or form scattered single crystals. Anhydrite crystals together with other insoluble minerals were separated by dissolution of blue halite. Then, anhydrite crystals were gently crushed because their surface roughness causes difficulties during microscopic examinations. Totally, about 200 anhydrite crystals were selected from 67 samples. Microthermometric measurements were carried on for groups of fluid inclusions which were clearly visible under the transparent light and which contained two phases with a constant vapour/liquid ratio.

Microthermometric measurements were conducted with a Linkam THMSG600 Geology Heating and Freezing Stage mounted on a NIKON ECLIPSE E600 microscope, using 20×, $50 \times$ and $100 \times$ objectives. The stage was calibrated using pure $\mathrm{CO}_{2}$ synthetic inclusions $\left(\mathrm{Tm}=-56.6^{\circ} \mathrm{C}\right)$ and known homogenisation temperature of pure $\mathrm{H}_{2} \mathrm{O}$ inclusions. A heating-freezing rate of $5^{\circ} \mathrm{C} / \mathrm{min}$ was applied with the accuracy of $0.1^{\circ} \mathrm{C}$. Individual anhydrite crystals were measured only once in order to avoid the effect of inclusion stretching outside the observation field of the microscope, where inclusion cannot be directly observed. Cycling was attempted in all homogenisation runs, in order to observe the proper homogenisation temperatures (Goldstein and Reynolds, 1994). An attention was paid also to the changes of inclusion shapes (Vanko and Bach, 2005). In case of noticeable changes, the measurements were interrupted.

In addition, selected samples were analysed with the Thermo Scientific ${ }^{T M}$ DXR Raman Microscope working in confocal mode, using $780 \mathrm{~nm}$ excitation line (diode laser, power: $24 \mathrm{~mW}$ ). The Olympus microscope with $10 \times, 50 \times$ and $100 \times$ objectives was used for laser focusing.

\section{RESULTS}

\section{SOLID INCLUSIONS IN ANHYDRITE CRYSTALS}

Anhydrite crystals are among the most frequent solid intergrowths observed in the blue halite crystals (Toboła and Natkaniec-Nowak, 2007, 2008). Such intergrowths vary in size from about 0.1 to $1 \mathrm{~mm}$. Their shapes are usually anhedral or rarely subhedral, often with slightly rounded edges. The majority of studied anhydrite crystals are characterized by rough and scaly surface (Fig. 4A). Under transmitted light, opaque intergrowths can be seen within some anhydrite grains, usually as scattered single grains or, less commonly, as small aggregates (Fig. 4B) from a few micrometres to about $20 \mu \mathrm{m}$ across. Their shapes vary from regular for the larger grains (Fig. 4C) through partly regular to rarely irregular for smaller examples. The Raman spectroscopy revealed that these solid intergrowths are pyrite grains (Fig. 4D). Occasionally, the large crystals occur within the fluid inclusion and occupy significant parts of their volume (Fig. 4E). As shown below, very small opaque minerals are relatively common in fluid inclusions.

Quartz is another interesting mineral encountered in blue-coloured halite. It was initially identified using the SEM-EDS method (Toboła and Natkaniec-Nowak, 2007, 2008). Separated quartz crystals are always euhedral and form elongated hexagonal prisms (Figs. 4F and 5A). Similarly to the anhydrite crystals, their surface is very often rough (Fig. 4F), which prevents observation of internal structure. More smooth surfaces are displayed only by rare crystals which form short prisms (Fig. 5A). Under the transparent light, such crystals reveal opaque intergrowths as well as very small (a few $\mu \mathrm{m})$ fluid inclusions. Quartz crystals are not only associated with halite but are also closely related to anhydrite. Such association de- 
A
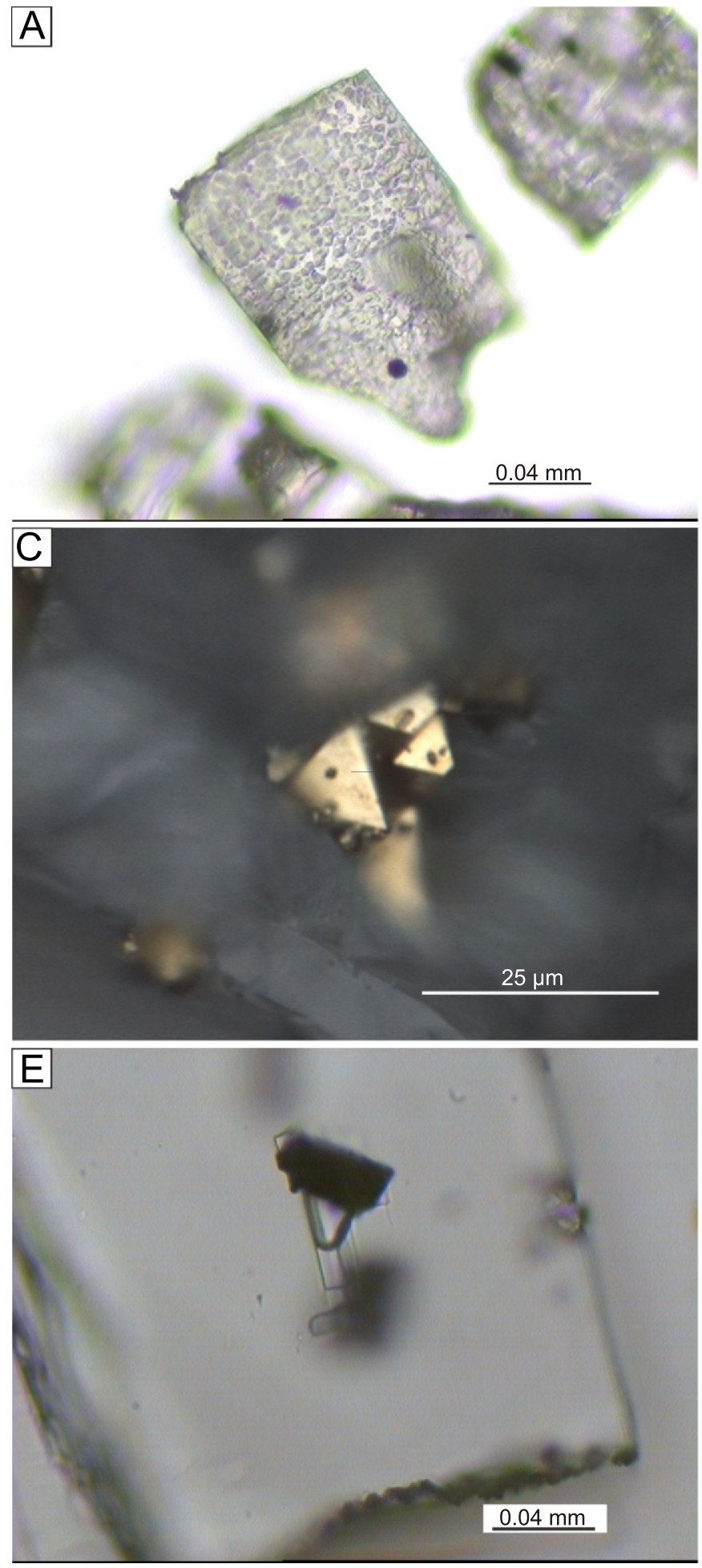

B

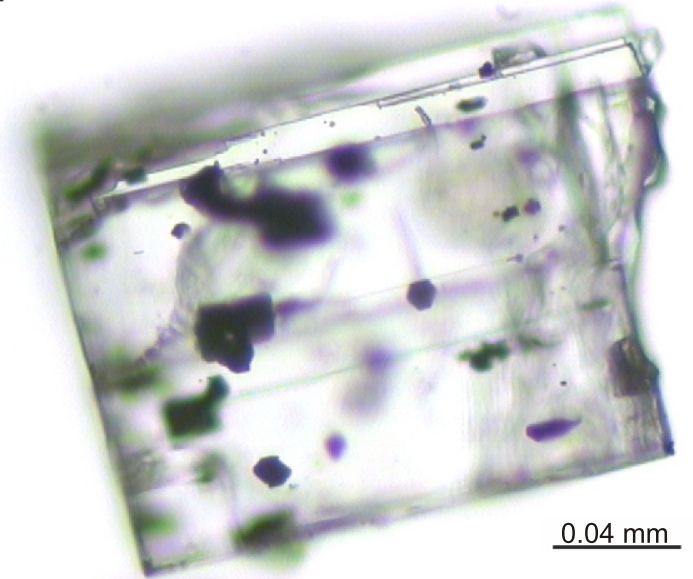

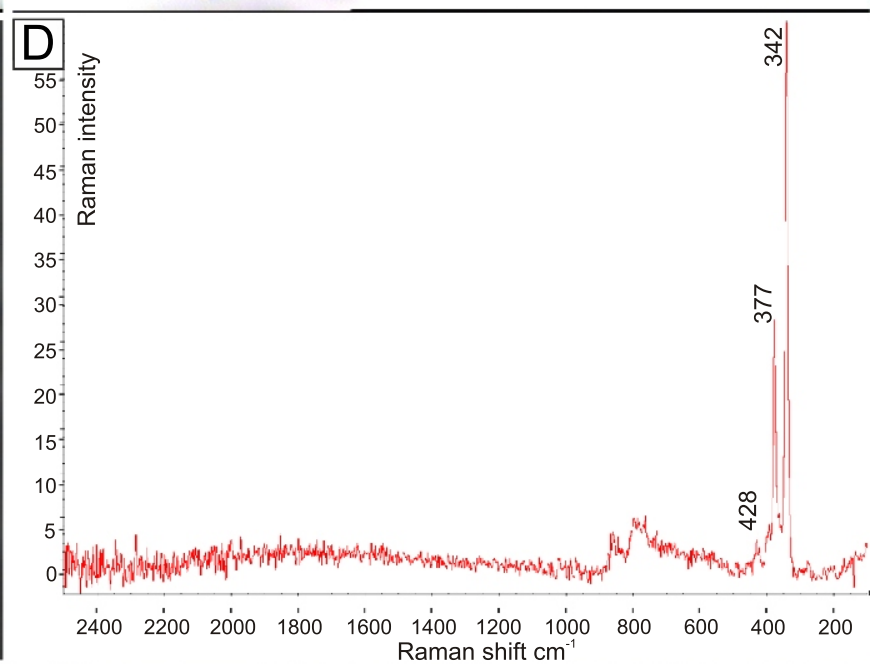

$\mathrm{F}$

00:42:19:05 50x Lens $12-05-00$

$\underline{0.04 \mathrm{~mm}}$

Fig. 4. Microscopic images

A - rough surface of anhydrite crystals; B - intergrowths of opaque minerals within anhydrite crystals (transmitted light); C - euhedral pyrite intergrowths in anhydrite crystal (reflected light); D - Raman spectra of pyrite intergrowth in C; E - solid intergrowths associated with two-phase fluid inclusion (transmitted light); F - euhedral quartz crystal with rough surface (transmitted light) 

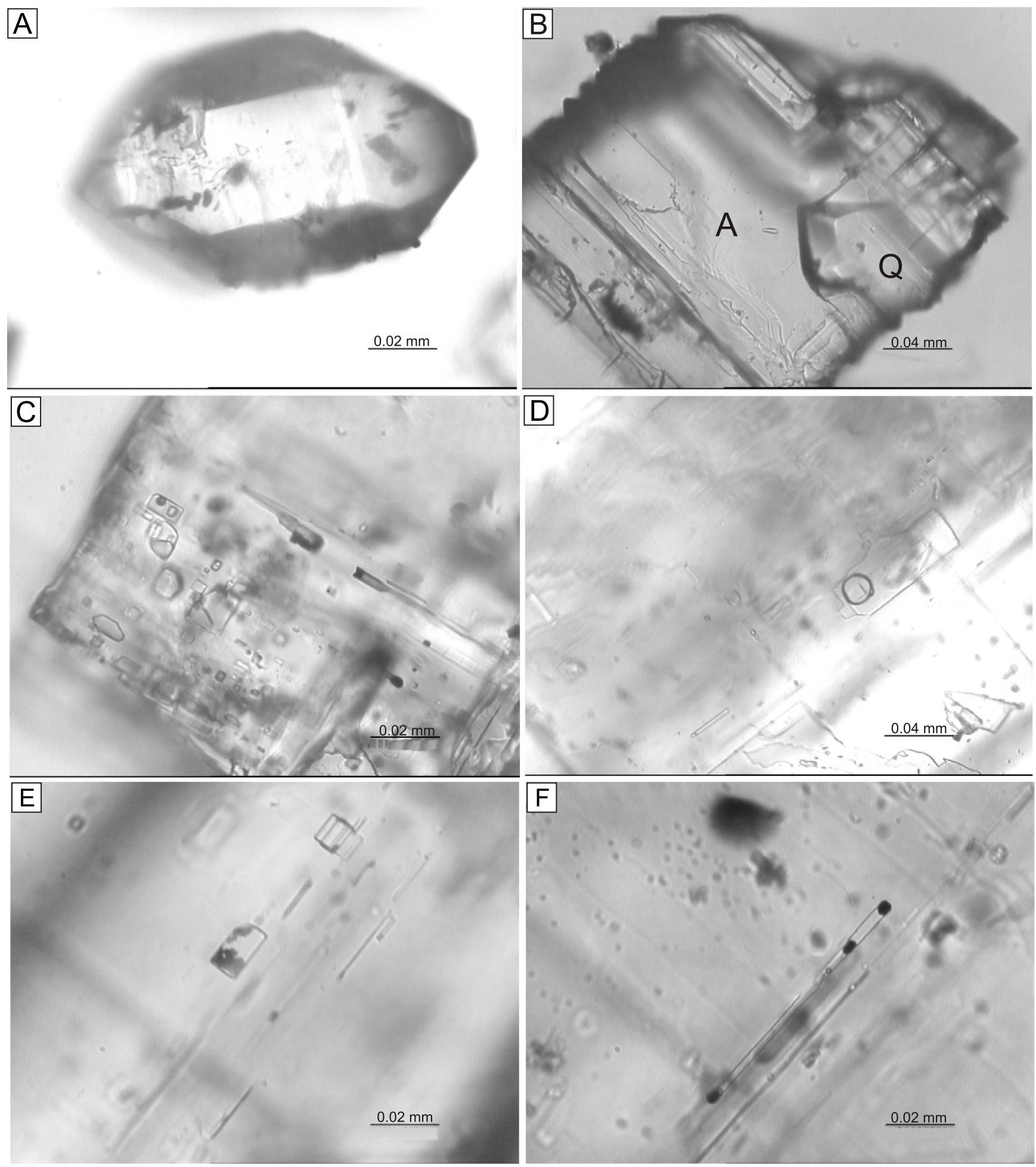

Fig. 5. Microscopic images (transmitted light)

A - short euhedral quartz crystals with smoother surface and small opaque intergrowths; B - anhydrite crystal (A) with intergrowths of euhedral quartz (Q); C - densely packed FIA in a part of anhydrite crystal, two shapes of inclusions are visible: regular, cuboid (on the left), and highly elongated, tubular (on the right and in the upper part), some inclusions contain opaque (mainly tubular) or transparent (mainly cuboid) minerals; D - one of the largest flattened two-phase inclusions; $\mathbf{E}$ - the group of small opaque minerals in large inclusion; $\mathbf{F}$ - tubular inclusion with single opaque minerals located at its terminations and in the centre (single inclusion), note that the mineral in the centre divides the inclusion into two parts of different diameters 
pends on the coexistence of both minerals when the quartz crystals are overgrown by the anhydrite ones (Fig. 5B). In some euhedral anhydrite crystals, observed under transmitted light, small (up to $20 \mu \mathrm{m}$ ) quartz grains can be seen, too.

\section{FLUID INCLUSIONS - PETROGRAPHY} AND MICROTHERMOMETRIC DATA

In most anhydrite crystals, fluid inclusions were absent or occurred only as single, randomly distributed species. Clusters composed of several small inclusions were also relatively uncommon although hunted because such forms provide more useful data. Larger accumulations of densely packed inclusions were observed only occasionally (Fig. 5C).

Two types of FIA were distinguished, depending on their relationships to crystallographic axes and mode of occurrence: primary and secondary (pseudosecondary) (e.g., Roedder, 1984a; Goldstein and Reynolds, 1994). The most common inclusions were those identified as primary. Among the whole population of the investigated crystals these inclusions differ in shape, size and filling materials.

Concerning the shape of inclusions, two groups were distinguished: the first one comprises regular, cuboid inclusions usually slightly extended along the $Z$ axis (rarely perpendicular to the $Z$ axis) or showing square cross sections. Their size varied from a few to several micrometres but occasionally exceeded $20 \mu \mathrm{m}$. Inclusions exceeding $50 \mu \mathrm{m}$ in size were found only in a few crystals (Fig. 5D). Under the transmitted light the majority of these inclusions seem to be flattened. Thicker and larger inclusions very often contain groups of opaque minerals in the form of small (up to about $2 \mu \mathrm{m}$ ), irregular, occasionally spherical grains (Fig. 5E). Furthermore, we observed also transparent daughter minerals of regular, cubic shapes indicating the presence of halite and sylvite, and rounded crystals.

The second group consists of tubular inclusions, strongly elongated along the $Z$ axis (Fig. 5F). Their length exceeds $50 \mu \mathrm{m}$ and the width is up to a few micrometres (3-5 $\mu \mathrm{m})$. Such inclusions very often contain small opaque minerals in their end parts.

Inclusions of both groups show very complex phase relations and chemical compositions. The phase ratios are highly variable between samples, but they appear highly or fully consistent in single crystals or in FIA. Therefore, the highest variability was observed between the crystals. In most crystals, gas to liquid $(\mathrm{GL})$ or liquid $\mathrm{CO}_{2}$ to liquid $\mathrm{H}_{2} \mathrm{O}(\mathrm{LL})$ ratios are in the range from 5 to $30 \%$ (Fig. $6 \mathrm{~A}$ ). Another group of FIA consists of inclusions containing $85-95 \%$ of vapour phase (Fig. 6B). Between these two types there are numerous FIAs which comprise inclusions showing intermediate or highly variable values of phase ratios (Fig. 6C).

Both the secondary and pseudosecondary inclusions in anhydrite crystals are more rare than the primary FIAs. These are arranged in narrow, sometimes curved or oblique rows (Fig. 6D). Such FIAs always consist of very small inclusions, up to a few micrometres across (rarely reaching $10 \mu \mathrm{m}$ ). Their shapes are irregular and rounded. In all cases these are liquid inclusions with small (up to 15\%) bubbles of gas phase.

In addition to the above-mentioned types, in a few cases we observed separate inclusions of questionable origin. Their shapes are either rounded and slightly elongated (Fig. 6E) or strongly elongated and tubular (Fig. 6F). The former are filled with the gas and liquid phases in similar proportions ( $50 \%$ $\mathrm{V} / \mathrm{L})$, whereas the latter are filled mostly with the gas phase hosting transparent daughter minerals which separate smaller parts of inclusion filled probably with the liquid phase.

Microthermometric measurements showed highly diversified behaviour of inclusions. During the heating, most of studied inclusions underwent decrepitation with a rapid jumping of crystals, which prevented further observations, or with a distinct unsealing, with often visible percolation of fluids through the cleavage planes. The temperatures of decrepitation and unsealing varied in a wide range, from 116 to $530^{\circ} \mathrm{C}$, but the most common values were from 350 to $450^{\circ} \mathrm{C}$ (Fig. 7). This indicates a high pressure within the inclusions and the possible presence of $\mathrm{CO}_{2}$ (e.g., Diamond, 2001). Such interpretation is supported by a common "swelling" of inclusions and evolution of their shapes to oval at higher temperatures (Vanko and Bach, 2005).

Reliable results of total homogenisation temperatures were obtained for only twenty-seven FIAs measured. The process of homogenisation showed two paths: to the liquid phase ( $L G \rightarrow L$ or $L L \rightarrow L)$ or to the gas phase ( $L G \rightarrow G)$, as revealed by the phase ratio. The first path was observed in inclusions with very low (5-10\%) gas/liquid of liquid/liquid ratios. The lowest homogenisation temperature $\left(174^{\circ} \mathrm{C}\right)$ was observed in a single inclusion, whereas other inclusions in this FIA remained unhomogenised, showing only shrinkage and movements of bubbles. At higher temperatures these inclusions showed unsealing or decrepitation. In the remaining eight inclusions, homogenisation temperatures varied from 371 to $513^{\circ} \mathrm{C}$ (Fig. 7). In the histogram (Fig. 7), the value $>520^{\circ} \mathrm{C}$ refers to the inclusions in which homogenisation could not be observed directly because the heating was conducted to the maximum temperature of $550^{\circ} \mathrm{C}$. However, these inclusions showed some features indicating the approaching homogenisation, e.g., gradual shrinkage of the bubbles and their rapid movements (Roedder, 1984a).

The second homogenisation path (towards the gas phase) provided reliable homogenisation temperatures only for nine inclusions, in which, after cooling to room temperature, the phase ratios returned to the initial values. We rejected all inclusions in which phase ratios did not return exactly to the original state due to unsealing invisible under the microscope. We also rejected the inclusions in which changes in shape (swelling) were observed. Generally, homogenisation towards the gas phase was found in gas-dominated inclusions, but it was also recorded in inclusions with a similar phase ratio (Fig. 6E). In comparison to the first homogenisation path (i.e., towards the liquid phase), the measured temperatures were lower and more consistent: from 224 to $385^{\circ} \mathrm{C}$ (Fig. 7).

For both the secondary and pseudosecondary inclusions, heating caused homogenisation only towards the liquid phase $(L G \rightarrow L)$. Measured temperatures varied in a wide range from 325 to $451^{\circ} \mathrm{C}$ although most such inclusions homogenised in the range of $400-500^{\circ} \mathrm{C}$ (Fig. 7).

During the cooling, highly variable behaviour of inclusions was observed. In some crystals of the two-phase (LL) inclusions, cooling caused nucleation of gas bubble within the original liquid bubble. This perfectly proves the presence of $\mathrm{CO}_{2}$ in the liquid phase (Sterner and Bodnar, 1991; Schmidt et al., 1995; Kirill and Graham, 1999; Bakker and Diamond, 2000; Schmidt and Bodnar, 2000; Diamond, 2001, 2003; Van den Kerkhof and Thiéry, 2001). In such cases, homogenisation temperatures $\left(T h_{c a r}\right)$ varied in a wide range (from -42 to $5.8^{\circ} \mathrm{C}$ ), indicating variable density of $\mathrm{CO}_{2}$.

During the subsequent cooling down to the temperature of $-192^{\circ} \mathrm{C}$, no visible changes were observed in most of the inclusions. Such behaviour may result from several reasons. First of 

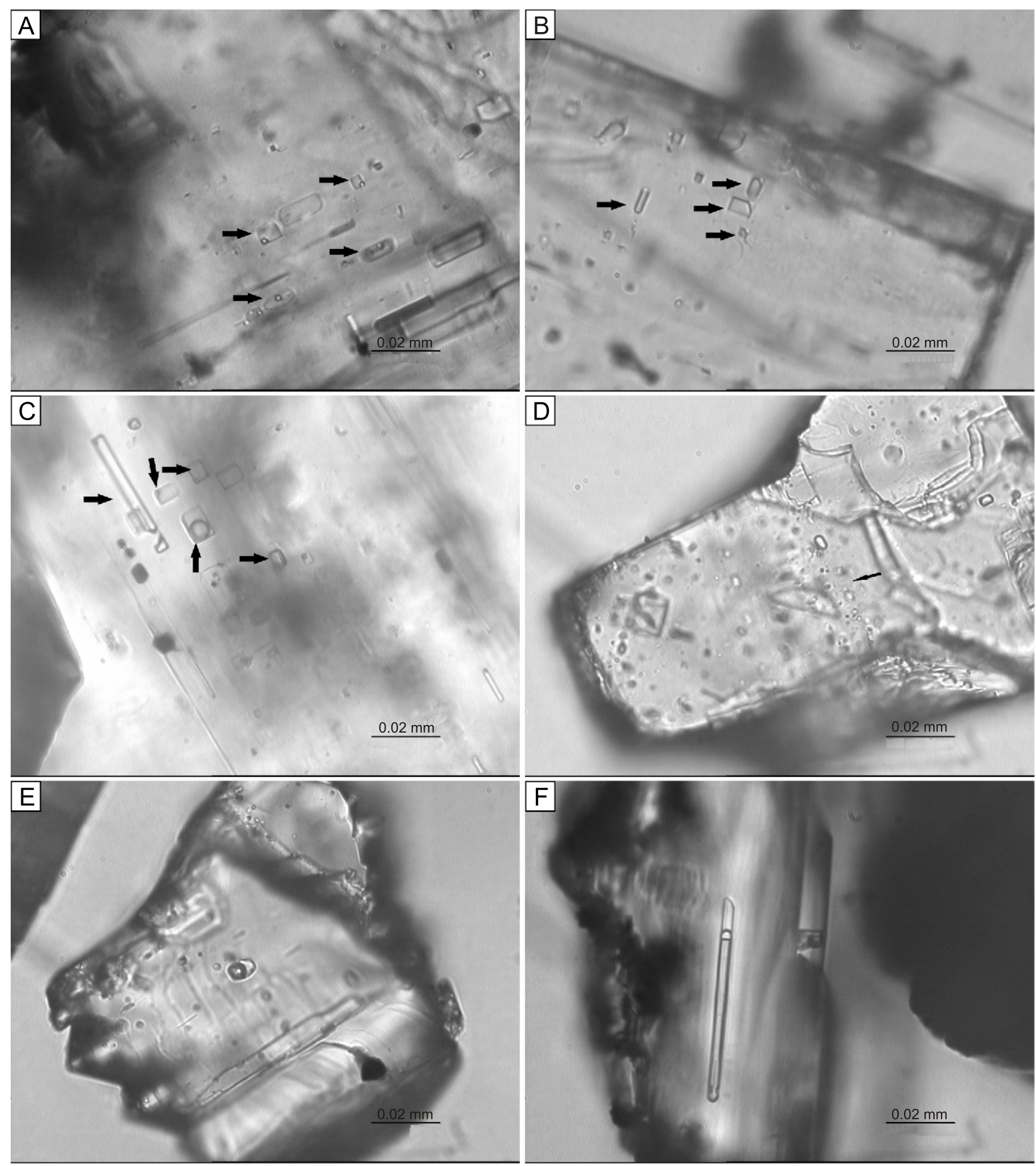

Fig. 6. Microscopic images (transmitted light)

A - FIA with constant and low gas/liquid ratio (marked by arrows); B - FIA with a significant prevalence of gas phase (marked by arrows); C inclusions with highly variable gas/liquid ratio (marked by arrows); D - secondary or pseudo-secondary inclusions; $\mathbf{E}$ - single inclusion (centre) filled with liquid and gas phases in similar proportions; $\mathbf{F}$ - tubular inclusion (centre) filled with gas phase (lower part of darker rim) 


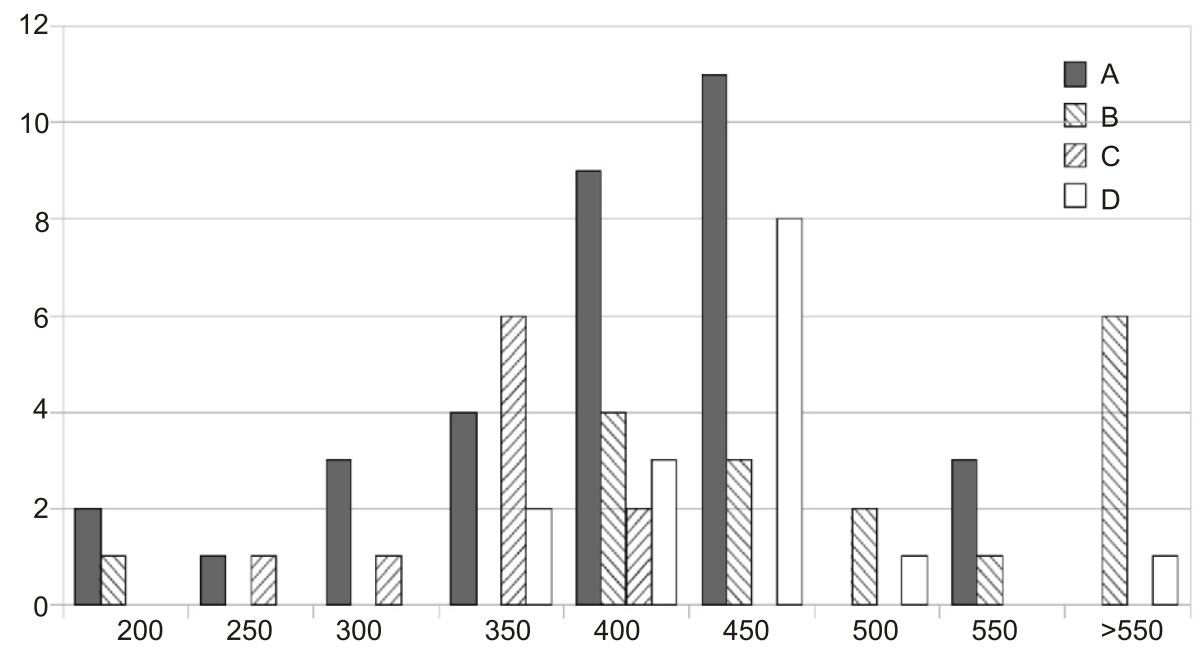

Fig. 7. Histogram of temperatures of:

A - decrepitation, B - primary fluid inclusions homogenising towards liquid phase, C - primary fluid inclusions homogenising towards gas phase, D - secondary fluid inclusions homogenising towards liquid phase

all, both the small size of inclusions and their flattened (tabular) shapes often precluded proper observations and interpretation (see e.g., Bodnar, 2003). The second reason can be the metastability of fluids presumably related to high salinity of the aqueous phase. As stated above, some observed inclusions contained daughter minerals (halite or sylvite) indicating that the migrating solution was fully saturated with respect to chlorine salts. In addition, we found intergrowths of sylvite and carnallite in blue halite, suggesting the presence of large amounts of potassium and magnesium in the percolating brines. Such a high salinity of brines enclosed in inclusions may result in their metastability during the cooling (Roedder, 1984a; Bodnar 2003; Diamond, 2003). Another reason of metastability may be the admixture of other volatiles, as $\mathrm{CH}_{4}$ or $\mathrm{H}_{2} \mathrm{~S}$ (Diamond, 2003). The presence of such gases was recorded in a few single-phase liquid inclusions, which nucleated gas bubbles during the cooling below $-100^{\circ} \mathrm{C}$ and freezing below $-140^{\circ} \mathrm{C}$. The melting temperatures were in the range from $-87.9^{\circ} \mathrm{C}$ to $-87.1^{\circ} \mathrm{C}$ and the homogenisation temperatures varied from $-61.5^{\circ} \mathrm{C}$ to $-60.5^{\circ} \mathrm{C}$. Such values may suggest the presence of $\mathrm{CH}_{4}$ in amounts of 80 mol.\% (Diamond, 2003).

\section{DISCUSSION}

The previous studies of the blue halite from the Kłodawa Salt Dome showed that its occurrences are closely connected with the epigenetic rocks and that it does not occur in primary salts, as yet (Natkaniec-Nowak and Toboła, 2003; Toboła et al., 2007; Janiów et al., 2008). The formation of such rocks was related to the migration of solutions rich in potassium and magnesium. The larger accumulations of blue halite were also related to disjunctive tectonic disturbances. Such a position of blue halite in the Kłodawa Salt Dome is in accordance with the occurrence of blue salts in other formations (Borchert, 1959; Boborov et al., 1968; Ivanov and Voronova, 1968, 1972; Roulston and Waugh, 1983; Waugh and Urquhart, 1983; Koriń, 1994; Sonnenfeld, 1995; Tabakh et al., 1999; Davison, 2009; Smetannikov, 2011). They occur most frequently in the vicinity of fractures, shear zones or faults where salts are subjected to crushing and brecciation. These processes facilitated the percolation of solutions, and recrystallisation and crystallisation of epigenetic salts (sylvite or carnallite). Within the blue halite crystals, solid inclusions of sylvite surrounded by colourless halo of halite were sometimes noticed. It may be an argument against the influence of radioactivity originating from potassium (Sonnenfeld, 1995). In the Kłodawa Salt Dome, similar features of blue halite were noticed very often (Heflik et al., 2008). Moreover, the blue halite veins also contain colourless halite crystals or large parts of crystals devoid of blue colouration with numerous sylvite inclusions. It may very well support the idea of insufficient effect of radiation of ${ }^{40} \mathrm{~K}$ from sylvite.

Analyses of anhydrite crystals separated from the largest accumulation of blue halite in the Kłodawa Salt Dome allowed us to determine their origin more precisely. Petrological observations and, especially, microthermometric studies revealed that the conditions of their formation were highly complicated and considerably different from the commonly accepted formation models of epigenetic evaporites in salt domes (e.g., Borchert and Muir, 1964; Kühn, 1968; Stańczyk, 1970; Braitsch, 1971; Stańczyk-Stasik, 1976). In these models, the main source of water is decomposition of hydrated minerals during the burial of salt formations (i.e., under increasing temperature and pressure) and the reactions between minerals. Such solutions have specific physicochemical properties controlled by the relationships between evaporite minerals and the burial depths. In this context, both the chemical and physical properties of solutions from which the anhydrite and other minerals (pyrite, quartz) as well as blue halite and other chlorine minerals have crystallised seem to be very variable.

The first indication of such unusual properties of solutions is the occurrence of euhedral pyrite and quartz within the anhydrite crystals (Figs. 4C, F and 5A, B). Their euhedral habits suggest that these minerals crystallised at the first stage, under free crystal growth conditions, from solutions with increased concentrations of iron, sulphide and silica. It is suggested that these minerals were the nuclei for subsequently crystallising anhydrite. 
The iron sulphides were still present in solution during the crystallisation of anhydrite crystals. These minerals crystallised at the surface of anhydrite, in the form of small subhedral crystals. Located close to each other, such embryonic crystals created barriers to the growth of anhydrite, and, thus, limited the formation of tubular inclusions (Fig. 5F) or more isometric inclusions (Fig. 5C, E) if larger accumulations were observed. Such genesis of inclusions is a relatively common phenomenon (e.g., Roedder, 1984a; Goldstein and Reynolds, 1994).

Microthermometric measurements indicated very clearly that anhydrite was formed under high-temperature conditions, i.e., at temperatures exceeding in most cases $250^{\circ} \mathrm{C}$. In some analysed crystals, formation temperatures significantly exceeded the critical point of water, which indicates high salinity of solutions (Knight and Bodnar, 1989). Such a temperature range cannot be explained in terms of burial of salt formation and development of the Kłodawa Salt Dome. According to the results of geological and geophysical studies, the Zechstein salt formation and the salts in the Kłodawa dome were not buried sufficiently deep to attain such high temperatures (e.g., Dadlez et al., 1995; Dadlez, 2003; Krzywiec, 2004, 2006). It is particularly valid for salts enclosed in the salt domes because the uplift of domes started in the Early and Middle Triassic (Krzywiec, 2004), and because the domes have not been covered by thick overburden.

Other important features which can be genetic indicators of solutions include the chemical composition and general behaviour during heating and cooling. Observations of inclusions confirmed the presence of liquid $\mathrm{CO}_{2}$ with considerable amounts of $\mathrm{CH}_{4}$ and, probably, also $\mathrm{H}_{2} \mathrm{~S}$. The occurrence of these components in the whole population of inclusions is highly variable, but in a single FIA or in fragments of anhydrite crystals the chemical composition is quite stable. This suggests that the migration environment was rather homogeneous, but it was subjected to rapid chemical changes in time. Considering the $P-T$ conditions, the variability of migration environment is also very well-pronounced by different directions of homogenisation (i.e., towards the liquid or gaseous phases), which indicates that the entrapment of fluids in inclusions took place first of all under highly variable pressures. Calculation of homogenisation pressure in inclusions using the programs of Bakker (2003, 2009, 2012) reveal the pressure in the range of 8.0-73.1 MPa for homogenisation toward the liquid phase and 3.9-27.2 MPa for homogenisation toward the gas phase. Therefore, solution densities (molar volumes) were also highly variable (see e.g., Roedder, 1984a; Goldstein and Reynolds, 1994; Diamond, 2003). On the contrary, formation temperatures seem to be less variable because no significant differences were observed between the temperatures of homogenisation towards the liquid and gas phases. Such behaviour of inclusions combined with high temperatures of homogenisation may be related to migration of hydrothermal solutions. According to numerous authors (e.g., Diamond, 1990, 2001; Xu and Pollard, 1999; Yao et al., 1999; Xu, 2000; Baker and Lang, 2001; Graupner et al., 2001; Wilkinson, 2001; Fedele et al., 2005), hydrothermal systems reveal high variability of the amount of volatile (gaseous) and non-volatile components, their mutual relations as well as $P-T$ conditions. The most common minerals which crystallise in such environments are quartz and numerous sulphides of heavy metals. This paragenesis was also found in the studied blue halite crystals accompanying the anhydrite. The quantitative predominance of the anhydrite over quartz and sulphides in blue salts is probably related to the secondary enrichment of primary hot solutions in calcium sulphate, which took place during migration through the salt formation.
A wide range of homogenisation temperatures measured in analysed anhydrite crystals is also typical of an environment in which several formation stages of different temperatures and pressures can be distinguished. Furthermore, in the hydrothermal veins, local pockets of vapour phases are common (Diamond, 1990, 2001). This fairly well explains the presence of the groups of inclusions within anhydrite crystals, which show homogenisation towards the gas phase.

The occurrence of hydrothermal veins in the upper part of the Kłodawa Salt Dome is a result of geological evolution of this structure, particularly of the tectonics of the sub-Zechstein basement. Analysis of seismic data from the Kłodawa region revealed a system of faults in the basement, which were responsible for tectonic subsidence during the Zechstein sedimentation. Such tectonic activity influenced the development of salt structures (Wagner et al., 2002; Krzywiec, 2004). Simultaneously, these faults might have been the pathways for migration of hydrothermal solutions (Fig. 8). When migrating through the salt formation, these solutions must have changed their chemical composition by dissolution of rocks in the oldest Zechstein cyclothems (Lower Anhydrite, Oldest Halite, probably also Oldest Potash and Upper Anhydrite). In this way, the solutions became enriched in $\mathrm{Ca}, \mathrm{Na}, \mathrm{K}$ and $\mathrm{Mg}$ sulphates and chlorides. Further ascension of hydrothermal solutions through the growing salt structure caused their gradual cooling and precipitation
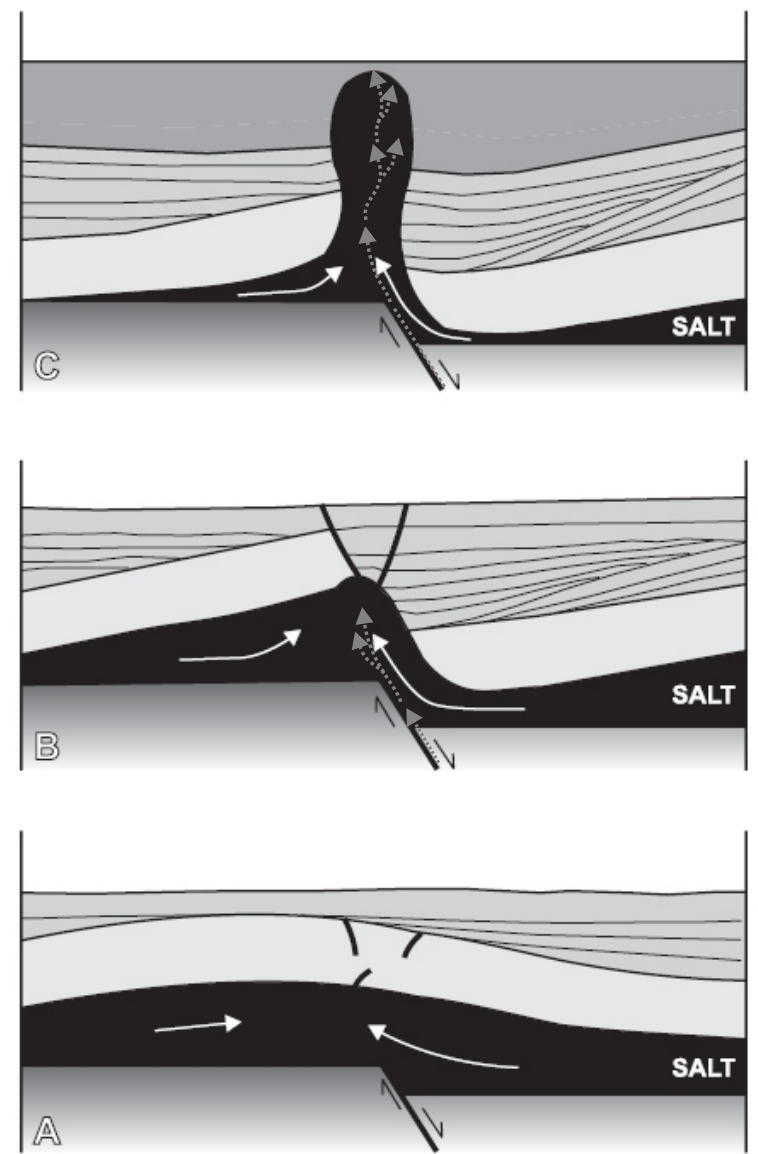

Fig. 8. Scheme of deformation evolution of salt structure with migration paths of hydrothermal solutions (after Koyi et al., 1993, modified)

White arrows - salt movement direction, grey arrows - direction of hydrothermal solutions migration 
of some minerals due to their solubilities at higher temperatures. Such mechanism explains very well the occurrence of numerous intergrowths of sylvite or carnallite in blue halite (Toboła and Natkaniec-Nowak, 2007, 2008).

The presence of hydrothermal solutions beneath the salt formation might have played a crucial role in the tectonic evolution of the Kłodawa Salt Dome. The migration of hot, high-pressured solutions through the salt formations significantly facilitated the vertical flow of salt masses. The leaching properties of solutions combined with high temperature and pressure might have influenced the tectonic movements because the solutions worked like a lubricant between the salt blocks. Moreover, their migration affected chemically and thermally the surrounding salts causing for example, precipitation of minerals which are not genetically related to the marine evaporites, e.g., borates (Wachowiak and Pieczka, 2012; Wachowiak and Toboła, 2014).

The other effect of migration of high-temperature solutions within the salt dome is the appearance of blue or viole colouration of halite crystals hosted within the salt layers. The colouration of halite is closely related to high temperatures (above $250^{\circ} \mathrm{C}$ ) providing energy as well as related to reducing conditions documented by the appearance of sulphides. The above-mentioned factors are probably responsible for the creation of defects, their migration and aggregation in the halite crystal structure. Presumably, an important role was played also by the high contents of potassium and sodium in solutions. Such conditions are in accordance with laboratory experiments of Kreutz (1892) who found that such colour of halite may be obtained by heating its crystals in potassium or sodium vapours although this mechanism applies only to some natural crystals. Similarly limited is the theory of radioactive damage of halite lattice caused by radiation from ${ }^{40} \mathrm{~K}$ isotope. Such mechanism of blue colouration of halite crystals is either not supported in natural environments or it plays rather minor role, as demonstrated by Sonnenfeld (1995) who summarized arguments against the radiation as the cause of halite colouration. However, even if temperature is considered as a main reason of halite colouration, unsolved remain the problems of colour variations and of the forms of colouration observed on the micro-scale within the single crystals (Heflik et al., 2008) and on the scale of particular exposures in mine workings (Natkaniec-Nowak and Toboła, 2003; Toboła et al., 2007; Janiów et al., 2008). Variability of blue colouration was observed also in artificially irradiated natural halite crystals (Schléder and Urai, 2005, 2007; Schléder et al., 2007, 2008) and interpreted generally as a result of stress. It must be emphasized that during the gamma-irradiation, the blue colouration of halite was obtained at the temperature of $100^{\circ} \mathrm{C}$, whereas at lower temperature $\left(35^{\circ} \mathrm{C}\right)$ the brown colour appeared.

Both the irradiation and the temperature cannot affect selectively only particular parts of halite accumulations. Therefore, additional factors are expected for both the emergence and the consolidation of colour. Some observations made at the Kłodawa Salt Mine suggest that the tectonic stress and, particularly, the strain developing in the shear zones may affect the crystal lattice of halite. Such evidence was found in the exposure located in chamber KS39, at the mining level $600 \mathrm{~m}$ (Fig. 3E) where the halite of intense blue colour occurs only at the contact of primary striped salts and the epigenetic halite-sylvite vein. Similar position of the main concentration of blue halite was observed in the exposure at the mining level 750 m (Janiów et al., 2008). Still, however, single blue halite crystals were encountered there within the carnallite vein (Fig. 3F). This position of blue halite suggests that these crystals are of primary or partly secondary (recrystallised) origin and they underwent tectonic disturbances. Such tectonic involve- ment caused defects of the halite structure, whilst colourless crystals might have precipitated in the veins during the later migration of the solutions. The blue halite streaks or single crystals inside the veins of epigenetic salts may be relics of the defected crystals. The smaller exposures in the Kłodawa Salt Dome do not show such unequivocal evidence, but all of them are strictly associated with shear zones (Toboła et al., 2007; Janiów et al., 2008).

These conditions of blue halite formation explain very well why there is no blue halite in the primary potassium-magnesium salts despite the presence of radioactive potassium isotope ${ }^{40} \mathrm{~K}$ in the ratio, normal for such sediments. Moreover, the migration of hydrothermal solutions through the Kłodawa Salt Dome might have resulted in the appearance of minerals which are not directly related to these formations, as boracite and congolite (Wachowiak and Pieczka, 2012; Wachowiak and Toboła, 2014). Influence of increasing temperature in the diapir was also mentioned by Wagner and Burliga (2014) for the Stinking Shale and the Main Dolomite. It was determined on the basis of measurements of random reflectance of organic matter

It should be pointed out that the contribution of temperature to the formation of blue halite in some salt deposits, as well as their association with igneous rocks or magmatic solutions, such as those found in salt deposits in Germany, is significant (Borchert, 1959). Moreover, blue halite was also found in a kimberlite pipe in the form of xenoliths (Polozov et al., 2008).

\section{CONCLUSIONS}

The origin of blue or violet halite crystals in natural environments has not been adequately explained so far. Numerous laboratory experiments using various methods of halite colouration do not reflect the natural conditions (Sonnenfeld, 1995). The most common opinion that radioactive decay of potassium ${ }^{40} \mathrm{~K}$ isotope is responsible for halite colouration does not explain adequately the accumulation of blue halite in the salt formations because, up to now, blue halite has not been found in the primary potassium salt beds.

Studies on anhydrite intergrowths in blue halite from one of the largest underground exposures in the Kłodawa Salt Dome indicate that blue colouration of halite is a combined effect of at least three factors: (1) high temperatures (above $250^{\circ} \mathrm{C}$ ) resulting from migration of hydrothermal solutions within the salt formation, (2) reducing conditions, as demonstrated by the occurrence of sulphide minerals, (3) defects of crystal structure, caused by the tectonic activity and, especially, by the stress developed in the shear zone.

The origin of hydrothermal solutions is related to the basement of Zechstein salt formations and to the development of salt diapirs (cf. Wagner and Burliga, 2014). Their migration through the salt formation caused the evolution of their chemical composition. First of all, the solutions became enriched in some ions: $\mathrm{K}, \mathrm{Mg}, \mathrm{Ca}, \mathrm{Na}, \mathrm{Cl}$ and $\mathrm{SO}_{4}$ due to dissolution of the lower part of the Zechstein salt formations. The processes of dissolution and recrystallisation facilitated the tectonic movements and the development of the salt diapir but they also resulted in changes of mineral composition of beds within the salt dome and in the appearance of minerals which are not typical of marine evaporites.

Acknowledgements. The investigations were supported by the AGH University of Science and Technology in Kraków, grant No. 11.11.140.320. Helpful comments by the referees, G. Czapowski and an anonymous one, are appreciated. 


\section{REFERENCES}

Baikpour, S., Zulauf, G., Sebti, A., Kheirolahi, H., Dietl, C., 2010. Analogue and geophysical modelling of the Garmsar Salt Nappe, Iran: constraints on the evolution of the Alborz Mountains. Geophysical Journal International, 182: 599-612.

Baker, T., Lang, J.R., 2001. Fluid inclusion characteristic of intrusion-related gold mineralization, Tombstone-Tungsten magmatic belt, Yukon Territory, Canada. Mineralium Deposita, 36: 563-582.

Bakker, R.J., 2003. Package FLUIDS 1. Computer programs for analysis of fluid inclusion data and for modelling bulk fluid properties. Chemical Geology, 194: 3-23.

Bakker, R.J., 2009. Package FLUIDS. Part 3: correlations between equations of state, thermodynamics and fluid inclusions. Geofluids, 9: 63-74.

Bakker, R.J., 2012. Package FLUIDS. Part 4: thermodynamic modelling and purely empirical equations for $\mathrm{H} 2 \mathrm{O}-\mathrm{NaCl}-\mathrm{KCl}$ solutions. Mineralogy and Petrology, 105: 1-2.

Bakker, R.J., Diamond, L.W., 2000. Determination of the composition and molar volume of $\mathrm{H}_{2} \mathrm{O}-\mathrm{CO}_{2}$ fluid inclusions by microthermometry. Geochimica et Cosmochimica Acta, 64: 1753-1764.

Bickham, M., 2012. Chemical analysis of blue halite. South-Central Section - 46th Annual Meeting (8-9 March 2012). GSA, Abstracts with Programs, 44: 8.

Bobrov, V.P., Korenievski, S.M., Rabitchenko, O.P., 1968. Lithology and stratigraphy of Kramatorskya formation of Donbass and mineralogical-petrographical characteristics of potash horizons (in Russian). Proceedings of the Russian Geological Research Institute (VSEGEI), 161: 80-116.

Bodnar, R.J., 2003. Interpretation of data from aqueous-electrolyte fluid inclusions. Mineralogical Association of Canada. Short Course Series, 32: 81-100.

Borchert, H., 1959. Ozeane Salzlagerstätten. Gebrüder Borntraeger, Berlin.

Borchert, H., Muir, R.O., 1964. Salt Deposits. The Origin, Metamorphism and Deformation of Evaporites. D. Van Nostrand Company, Ltd, London.

Braitsch, O., 1971. Salt Deposits. Their Origin and Composition. Springer, New York.

Burliga, S., 1994. Tension gashes in the Platy Dolomite (Zechstein) of SW part of the Kłodawa Diapir (Central Poland) - kinematic implication) (in Polish with English summary). Przegląd Geologiczny, 42: 99-102.

Burliga, S., 2014. Heterogeneity of folding in Zechstein (Upper Permian) salt deposits in the Kłodawa Salt Structure, central Poland. Geological Quarterly, 58 (3): 565-576.

Burliga, S., Kolonko, P., Misiek, G., Czapowski, G., 1995. Kłodawa salt mine. In: Upper Rotliegend - Zechstein: Terrestrial - Marine Sedimentary Succession in Polish Permian Basin (ed. J. Małecka): 45-54. XIII International Congress on Carboniferous-Permian, August 28-September 2, 1995, Guide to Excursion A3, Kraków, Poland.

Charysz, W., 1973. Zechstein stage of Younger Salts (Z3) in Kujawy region (in Polish with English summary). Prace Geologiczne, 75: 1-68.

Dadlez, R., 2003. Mesozoic thickness pattern in the Mid-Polish Trough. Geological Quarterly, 47 (3): 223-240.

Dadlez, R., Narkiewicz, M., Stephenson, R.A., Visser, M.T.M., van Wees, J.D., 1995. Tectonic evolution of the Mid-Polish Trough: modelling implications and significance for central European geology. Tectonophysics, 252: 179-195.

Davison, I., 2009. Faulting and fluid flow through salt. Journal of the Geological Society, 166: 205-216.

Diamond, L.W., 1990. Fluid inclusion evidence for P-V-T-X evolution of hydrothermal solutions in Late-Alpine gold-Quartz veins at Brusson, Val d'Ayas, NW Italian Alps. American Journal of Science, 290: 912-958.

Diamond, L.W., 2001. Review of the systematics of $\mathrm{CO}_{2}-\mathrm{H}_{2} \mathrm{O}$ fluid inclusions. Lithos, 55: 69-99.
Diamond, L.W., 2003. Introduction to gas-bearing, aqueous fluid inclusions. Mineralogical Association of Canada, Short Course Series, 32: 101-158.

Fedele, L., Raia, F., Sasaki, M., Sawaki, T., Tarzia, M., Sasada, M., 2005. Fluid inclusion study constraining the hydrothermal evolution of caldera-forming volcanic systems in the Sengan Area, Northern Honshu, Japan. Mineralogy and Petrology, 84: 189-213.

Garlicki, A., Szybist, A., 1986. Saline deposits of Polish Zechstein with potash salts (in Polish with English summary). Gospodarka Surowcami Minerlnymi, 2: 389-404.

Goldstein, R.H., Reynolds, T.J., eds., 1994. Systematics of fluid inclusions in diagenetic minerals. SEPM Short Course, 31.

Graupner, T., Bray, C.J., Spooner, E.T.C., Herzig, P.M., 2001. Analysis of fluid inclusions in seafloor hydrothermal precipitates: testing and application of an integrated GC/IC technique. Chemical Geology, 177: 443-470.

Heflik, W., Natkaniec-Nowak, L., Toboła, T., 2008. Badania mikroskopowe soli niebieskich (in Polish) In: Sole niebieskie w wysadzie kłodawskim (eds. T. Toboła and L. Natkaniec-Nowak): 56-69. Uczelniane Wyd. Nauk.-Dydaktyczne AGH.

Ivanov, A.A., Voronova, M.L., 1968. Geology of the Verkhnepetchora sedimentary basin and its potash bearing features (in Russian). Proceedings of the Russian Geological Research Institute (VSEGEI), 161: 3-79.

Ivanov, A.A., Voronova, M.L., 1972. Salt-bearing Formations (in Russian). Russian Geological Research Institute (VSEGEI). Edition NEDRA, Moscow.

Janiów, S., Misiek, G., Toboła, T., Natkaniec-Nowak, L., 2008. Występowanie soli niebieskich w kopalni Kłodawa (in Polish) In: Sole niebieskie $w$ wysadzie kłodawskim (eds. T. Toboła and L. Natkaniec-Nowak): 24-53. Uczelniane Wyd. Nauk.-Dydaktyczne AGH.

Kirill, I., Graham, C.M., 1999. An experimental study of phase equilibria in the system $\mathrm{H}_{2} \mathrm{O}-\mathrm{CO}_{2}-\mathrm{NaCl}$ at $800^{\circ} \mathrm{C}$ and 9 kbar. Contributions to Mineralogy and Petrology, 136: 247-257.

Knight, C.L., Bodnar, R.J., 1989. Synthetic fluid inclusions: IX. Critical PVTX properties of $\mathrm{NaCl}-\mathrm{H}_{2} \mathrm{O}$ solutions. Geochimica et Cosmochimica Acta, 53: 3-8.

Koriń, S.S., 1994. Budowa geologiczna mioceńskich formacji solonośnych ukraińskiego Przedkarpacia (in Polish). Przegląd Geologiczny, 42: 744-747.

Koyi, H., Jenyon, M.K., Petersen, K., 1993. The effects of basement faulting on diapirism. Journal of Petroleum Geology, 16: 285-312.

Kreutz, F., 1892. O przyczynie niebieskiego zabarwienia soli kuchennej: 194-205 Akademia Umiejętności, Kraków.

Krzywiec, P., 2004. Triassic evolution of the Kłodawa salt structure: basement-controlled salt tectonics within the Mid-Polish Trough (Central Poland). Geological Quarterly, 48 (2): 123-134.

Krzywiec, P., 2006. Structural inversion of the Pomeranian and Kuiavian segments of the Mid-Polish Trough lateral variations in timing and structural style. Geological Quarterly, 50 (1): 151-168.

Kühn, R., 1968. Geochemistry of German potash deposits. GSA Special Papers, 88: 427-504.

Natkaniec-Nowak, L., Toboła, T., 2003. Blue salt from Kłodawa (Kujawy, Poland) (in Polish with English summary). Przegląd Geologiczny. 51: 435-438.

Polozov, A.G., Sergey, S., Sukhov, S.S., Gornova, M.A., Grishina, S.N., 2008. Salts from Udachnaya-East kimberlite pipe (Yakutia, Russia): occurrences and mineral composition. 9th International Kimberlite Conference Extended Abstract No. 9IKC-A-00247: 1-3.

Pustyl'nikov, A.M., 1975. Origin of blue color in halite in Cambrian salt deposits of the Siberian Platform (in Russian). Litologiya i Poleznye Iskopaemye, 10: 388-389.

Rahimpour-Bonab, H., Alijani, N., 2003. Petrography, diagenesis and depositional model for potash deposits of north Central Iran, 
and use of bromine geochemistry as a prospecting tool. Carbonates and Evaporites, 18: 19-28

Roedder, E., 1984a. Fluid inclusions. Reviews in Mineralogy, 12 $1-644$.

Roedder, E., 1984b. The fluid in salt. American Mineralogist, 69: 413-439.

Roulston, B.V., Waugh, D.C.E., 1983. Stratigraphic comparison of the Mississippian potash deposits in New Brunswick, Canada. Sixth International Symposium on Salt, 1: 115-129.

Schléder, Z., Urai, J.L., 2005. Microstructural evolution of deformation-modified primary halite from the Middle Triassic Röt Formation at Hengelo, The Netherlands. International Journal of Earth Sciences, 94: 941-955.

Schléder, Z., Urai, J.L., 2007. Deformation and recrystallization mechanisms in mylonitic shear zones in naturally deformed extrusive Eocenee-Oligocene rocksalt from Eyvanekey plateau and Garmsar hills (central Iran). Journal of Structural Geology, 29: 241-255.

Schléder, Z., Burliga, S., Urai, J.L., 2007. Dynamic and static recrystallization-related microstructures in halite samples from the Klodawa salt wall (central Poland) as revealed by gamma-irradiation. Neues Jahrbuch für Mineralogie Abhandlungen, 184 17-28.

Schléder, Z., Urai, J.L., Nollet, S., Hilgers, C., 2008. Solution-precipitation creep and fluid flow in halite: a case study of Zechstein (Z1) rocksalt from Neuhof salt mine (Germany). International Journal of Earth Sciences, 97: 1045-1056.

Schmidt, C., Bodnar, J., 2000. Synthetic fluid inclusions: XVI. PVTX properties in the system $\mathrm{H}_{2} \mathrm{O}-\mathrm{NaCl}-\mathrm{CO}_{2}$ at elevated temperatures, pressures, and salinities. Geochimica et Cosmochimica Acta, 64: 3853-3869.

Schmidt, C., Rosso, K.M., Bodnar, J.R., 1995. Synthetic fluid inclusions: XIII. Experimental determination of PVT properties in the system $\mathrm{H}_{2} \mathrm{O}+40 \mathrm{wt} \% \mathrm{NaCl}+5 \mathrm{~mol} \% \mathrm{CO}_{2}$ at elevated temperature and pressure. Geochemica et Cosmochimica Acta, 59: 3953-3959

Smetannikov, A.F., 2011. Hydrogen generation during the radiolysis of crystallization water in carnallite and possible consequences of this process. Geochemistry International, 49 916-924.

Sonnenfeld, P., 1995. The color of rock salt - a review. Sedimentary Geology, 94: 267-276.

Stadnicka, K., Zelek, S., 2008. Badania strukturalne soli niebieskich oraz faz stałych z inkluzji w halicie (in Polish). In: Sole niebieskie $w$ wysadzie kłodawskim (eds. T. Toboła and L. Natkaniec-Nowak): 100-116. Uczelniane Wyd. Nauk.-Dydaktyczne AGH.

Stańczyk, l., 1970. Polyhalite in the salt mines of the Kujawy region (in Polish with English summary). Acta Geologica Polonica, 20: 805-821.

Stańczyk-Stasik, I., 1976. Les dépots čpigénétiques dans les mines de sel de la région de Kujawy (in Polish with French summary). Prace Geologiczne, 90: 1-64.

Sterner, S.M., Bodnar, R.J., 1991. Synthetic fluid inclusions. X: Experimental determination of $\mathrm{P}-\mathrm{V}-\mathrm{T}-\mathrm{X}$ properties in the system $\mathrm{CO}_{2}-\mathrm{H}_{2} \mathrm{O}$ system to $6 \mathrm{~KB}$ and $700 \mathrm{C}$. American Journal of Science, 291: 1-54

Suwanich, P., 1983. Potash and rock salt in Thailand. Conference on Geology and Mineral Resources of Thailand, Bangkok 19-28 November: 241-252.

Tabakh, M.E., Utha-Aroon, Ch., Schreiber, B.Ch., 1999 Sedimentology of the Cretaceous Maha Sarakham evaporites in the Khorat Plateau of northeastern Thailand. Sedimentary Geology, 123: 31-62.

Tarka, R., 1992. Tectonics of some salt deposits in Poland based on mesostructural analysis) (in Polish with English summary) Prace Państwowego Instytutu Geologicznego, 137: 1-47.

Toboła, T., Natkaniec-Nowak, L., 2007. Solid phase inclusions in blue halite from Klodawa Salt Mine in the light of SEM-EDS analysis. XII International Salt Symposium „Quo Vadis Sal”. October 10-11, 2007, Kłodawa.
Toboła, T., Natkaniec-Nowak, L., 2008. Badania mikroskopem elektronowym (SEM-EDS) inkluzji stałych (in Polish). In: Sole niebieskie $\mathrm{w}$ wysadzie kłodawskim (eds. T. Toboła and L. Natkaniec-Nowak): 70-80. Uczelniane Wyd. Nauk.-Dydaktyczne AGH.

Toboła, T., Wesełucha-Birczyńska, A., 2008. Inkluzje fluidalne w halicie niebieskim (in Polish). In: Sole niebieskie w wysadzie kłodawskim (eds. T. Toboła and L. Natkaniec-Nowak): 81-99. Uczelniane Wyd. Nauk.-Dydaktyczne AGH

Toboła, T., Natkaniec-Nowak, L., Szybist A., Misiek, G., Janiów, S., 2007. Blue salts in Kłodawa Salt Mine (in Polish with English summary). Gospodarka Surowcami Mineralnymi, 23: 117-132.

Van den Kerkhof, A.M., Thiéry, R., 2001. Carbonic inclusions. Lithos, 55: 49-68.

Vanko, D.A., Bach, W., 2005. Heating and freezing experiments on aqueous fluid inclusions in anhydrite: recognition and effects of stretching and the low-temperature formation of gypsum. Chemical Geology, 223: 35-45.

Vinokurov, V.M., 1958. Blue rock salt from the Solikamsk district (in Russian). Zapisy Vsesoyuznogo Mineralogicheskogo Obshchestva (Proceedings of the All-Union Mineralogical Society), 87: 504-507.

Wachowiak, J., Pieczka, A., 2012. Congolite and trembatite from the Kłodawa Salt Mine, central Poland: record of the thermal history of the parental salt dome. The Canadian Mineralogist, 50: 1387-1399.

Wachowiak, J., Toboła, T., 2014. Phase transitions in the borate minerals from the Kłodawa Salt Dome (Central Poland) as indicators of temperature processes in salt diapirs. Geological Quarterly, 58 (3): 543-554.

Wagner, M., Burliga, St., 2014. Coalified bitumens from the Kłodawa Salt Structure (central Poland) as evidence of migration of hydrothermal fluids in Zechstein (Upper Permian) deposits. Geological Quarterly, 58 (3): 555-564.

Wagner, R., Leszczyński, K., Pokorski, J., Gumulak, K., 2002 Palaeotectonic cross-sections through the Mid-Polish Trough. Geological Quarterly, 46 (3): 293-306.

Waugh D.C.E., Urquhart, B.R., 1983. The geology of Denison-Potacan's New Brunswick potash deposit. Sixth International Symposium on Salt, 1: 85-98.

Werner, Z., Poborski, J., Orska, J., Bąkowski, J., 1960. A geological and mining outline of the Kłodawa salt deposit (in Polish with English summary). Prace Instytutu Geologicznego, 30 467-495.

Wesełucha-Birczyńska, A., Toboła, T., Natkaniec-Nowak, L., 2008. Raman microscopy of inclusions in blue halites. Vibrational Spectroscopy, 48: 302-307.

Wilkinson, J.J., 2001. Fluid inclusions in hydrothermal ore deposits. Lithos, 55: 229-272.

Xu, G., 2000. Fluid inclusions with $\mathrm{NaCl}-\mathrm{CaCl}_{2}-\mathrm{H}_{2} \mathrm{O}$ composition from the Cloncurry hydrothermal system, NW Queensland, Australia. Lithos, 53: 21-35.

Xu, G., Pollard P.J., 1999. Origin of $\mathrm{CO}_{2}$-rich fuid inclusions in synorogenic veins from the Eastern Mount Isa Fold Belt, NW Queensland, and their implications for mineralization. Mineralium Deposita, 34: 395-404.

Yao, Y., Morteani, G., Trumbull, R.B., 1999. Fluid inclusion microthermometry and the P-T evolution of gold-bearing hydrothermal fuids in the Niuxinshan gold deposit, eastern Hebei province, NE China. Mineralium Deposita, 34: 348-365.

Zelek, S., Stadnicka, K., Szklarzewicz, J., Natkaniec-Nowak, L., Toboła, T., 2007. Halite from Kłodawa: an attempt of correlation between the degree of crystal structure deformation and the spectroscopic properties in UV-VIS range. XII International Salt Symposium „Quo Vadis Sal”. October 10-11, 2007, Kłodawa: 61-62.

Zelek, S., Stadnicka, K., Toboła, T., Natkaniec-Nowak, L., 2014. Lattice deformation of blue halite from Zechstein evaporite basin: Kłodawa Salt Mine, Central Poland. Mineralogy and Petrology, 108: 619-631. 